УДК 635.21: 631.17

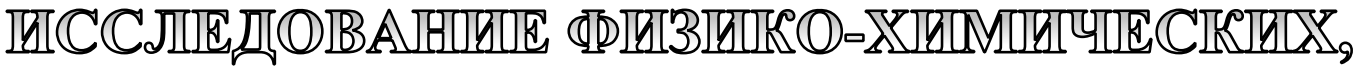

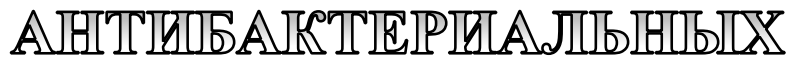

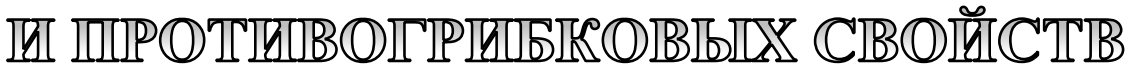

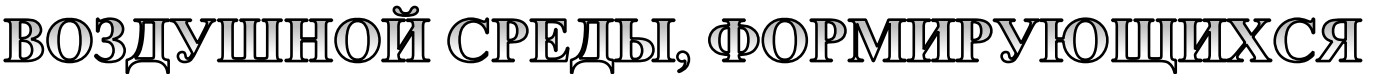

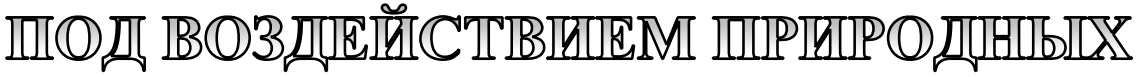

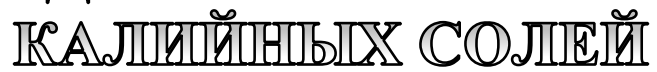

\author{
А.В. Шалимов, Горный институт УрО РАН \\ А.Ю. Максимов, Институт экологии и генетики микроорганизмов УрО РАН \\ А.Г. Исаевич, Горный институт УрО РАН \\ Л.Г. Цёма, Пермский научно-исследовательский институт сельского хозяйства УрО РАН
}

\section{Для цитирования:}

Шалимов А.В., Максимов А.Ю., Исаевич А.Г., Цёма Л.Г. Исследование физико-химических, антибактериальных и противогрибковых свойств воздушной среды, формирующихся под воздействием природных калийных солей // Вестник Пермского федерального исследовательского центра. - 2021. - № 2. - С. 34-46. https://doi.org/10.7242/2658-705X/2021.2.4

Россия обладает огромным потенциалом выращивания сельскохозяйственной продукции. В связи с этим вопросы сохранения выращенного урожая и минимизации потерь при хранении, которые могут достигать 30-50\%, являются весьма актуальными. В настоящее время известны способы хранения сельскохозяйственных культур в хранилищах с активной и естественной вентиляцией в буртах, закромах, контейнерах, оборудованных системами проветривания и поддержания температуры и влажности воздуха. Однако указанные способы не обеспечивают высокой сохранности продукции, заложенной на длительное хранение.

Перспективным направлением решения этих проблем является использование бактерицидных свойств воздушной среды, контактирующей с природными калийными солями. Верхнекамское месторождение калийных солей - одно из крупнейших в России - содержит треть мировых запасов, которые используются, в основном, для производства калийных удобрений. Однако уникальные фризико-химические свойства природных солей калия, натрия, магния, а также их механические и фильтрационные характеристики позволяют значительно расширить области их использования. В связи с этим в работе описаны результаты исследований свойств атмосферы, контактирующей с природными калийно-магниевыми солями и ее воздействие на фитопатогены. Оценка влияния соленасыщенной атмосферы на Phytophthora infestans выявила выраженную зависимость роста Phytophthora infestans от влажности среды и большую степень подавления роста микроорганизмов в насыщенной аэроионами атмосфрере. Подавление роста культуры данного фритопатогена достигало 39,5\% при влажности 16\%, 48,3\% - при влажности 50\% и 63,1\% - при влажности 85\%. Эксперименты по хранению картофреля в атмосфрере, контактирующей 
с природными калийными солями, показали минимальное поражение клубней фитопатогенами при использовании насыпной поверхности калийной соли.

Ключевые слова: природные калийно-магниевые соли, хранение картофеля, аэроионы, фитопатогены, заболеваемость клубней.

Еще в 90-х годах основатель Горного института д-р техн. наук, профессор А.Е. Красноштейн занимался вопросами нетрадиционного использования природных калийно-натриевых солей. Работы возглавляемого им коллектива шли в двух направлениях - «спелеотерапия» и использование физико-химических свойств солей в сельском хозяйстве (в частности, для хранения сельскохозяйственной продукции). Для повышения сохранности овощей было проведено несколько экспериментов и получены положительные результаты, однако дальнейшие исследования на эту тему не проводились.

Важной особенностью калийно-магниевых руд, во многом определяющих их свойства, является естественная радиоактивность, создаваемая присутствующими в рудах радиоактивными элементами.

Было показано, что формирование естественного радиоактивного фона калийных рудников обусловлено радиоактивным изотопом калия. Известно, что в составе калия обнаруживаются два стабильных изотопа: ${ }^{39} \mathrm{~K}(93,08 \%),{ }^{41} \mathrm{~K}(6,91 \%)$ и один радиоактивный $-{ }^{40} \mathrm{~K}(0,0119 \%)$. В результате $\beta$-распада (88\%), верхняя энергия спектра которого составляет $1,36 \mathrm{MэB},{ }^{40} \mathrm{~K}$ превра- щается в стабильный изотоп кальция ${ }^{40} \mathrm{Ca}$. В результате $\gamma$-распада, т. е. путем К - захвата $(12 \%),{ }^{40} \mathrm{~K}$ превращается в аргон-40 $\left({ }^{40} \mathrm{Ar}\right)$ с выделением $\gamma$-кванта с энергией 1,46 МэВ. Период полураспада калия-40 составляет $1,32 \times 109$ лет.

Для оценки аэроионного фона воздушной среды, контактирующей с калийными солями, проведены замеры концентрации легких аэроионов в атмосфере, контактирующей с сильвинитовой и соляной породами и в контрольном помещении, не облицованном соляными блоками. Эксперименты проводились в трех помещениях (камерах), облицованных сильвинитовыми и соляными блоками в течение трех дней. На рис. 1 представлены графики изменения суммарной концентрации легких аэроионов в атмосфере сильвинитовой, соляной и контрольной камер.

Анализ результатов замеров показал (рис. 2), что средняя концентрация аэроионов в сильвинитовой камере в первый день исследования составляет 5100 ионов в $\mathrm{cm}^{3}$, в соляной -800 ионов в см${ }^{3}$, в контрольной -100 ионов в см³. Таким образом, концентрация легких аэроионов в сильвинитовой камере в 6,3 раза выше, чем в соляной камере, и в 51 раз выше

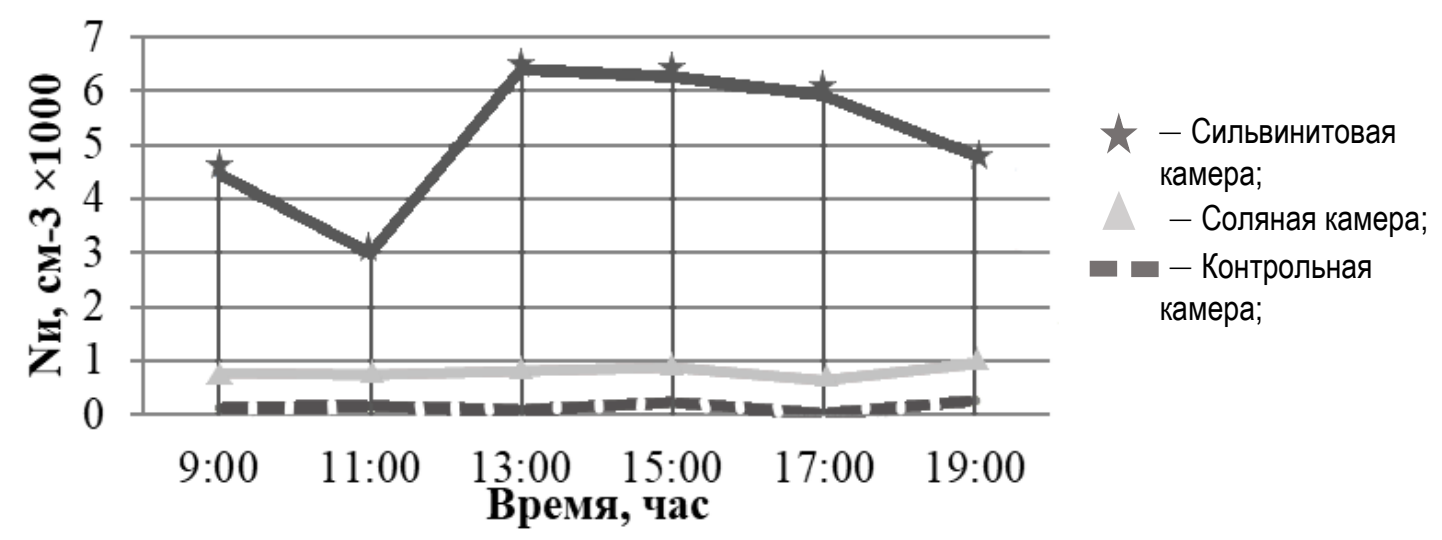

Рис. 1. Изменение суммарной концентрации легких аэроионов (обоих знаков Nи) в течение первого дня; Nu-суммарная концентрация легких ионов 


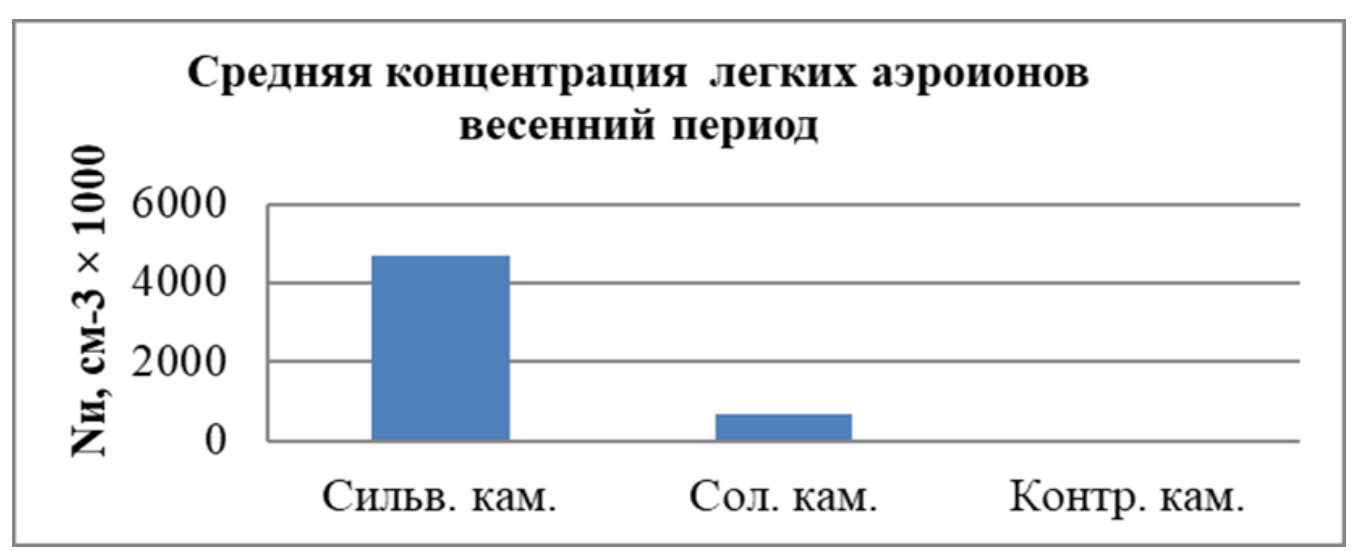

Рис. 2. Средняя суммарная концентрация легких аэроионов в камерах

фоновых значений в контрольной камере. Аналогичные результаты наблюдаются и в последующие дни замеров.

В целом, по итогам трехдневных замеров можно сделать вывод о том, что средняя суммарная концентрация легких аэроионов в атмосфере, контактирующей с сильвинитом, составляет 4636 ионов в $\mathrm{cm}^{3}$, с каменной солью 696 ионов в $\mathrm{cm}^{3}$ и 46 ионов в см ${ }^{3}-$ в контрольной камере.

Для выявления возможной зависимости концентрации легких аэроионов от общей площади поверхности сильвинита была изготовлена панель, облицованная прессованной сильвинитовой плиткой, позволяющая изменять количество плиток в панели, а значит, и свободную площадь сильвинитовой поверхности. Помимо пло- щади в эксперименте изменялись расстояния точки замера до панели. В процессе эксперимента площадь сильвинитовой поверхности составляла от 0,67 до $4,27 \mathrm{~m}^{2}$, расстояние до панели от 0,2 до $2 \mathrm{M}$.

Влияние площади панели и расстояния на концентрацию легких аэроионов представлено на рис. 3. При малых размерах панелей $\left(0,67 \mathrm{~m}^{2}\right.$ и $\left.1,35 \mathrm{~m}^{2}\right)$ превышение концентрации легких аэроионов над средним фоновым значением $\left(n \pm \approx 165 \mathrm{~cm}^{-3}\right)$ было невысоким: от 1,3 до 2,7 раза, при больших размерах

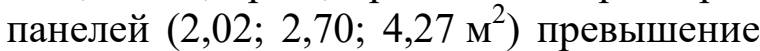
заметно возрастало. Зависимости концентрации легких аэроионов от размеров облицованной поверхности практически на всех расстояниях от

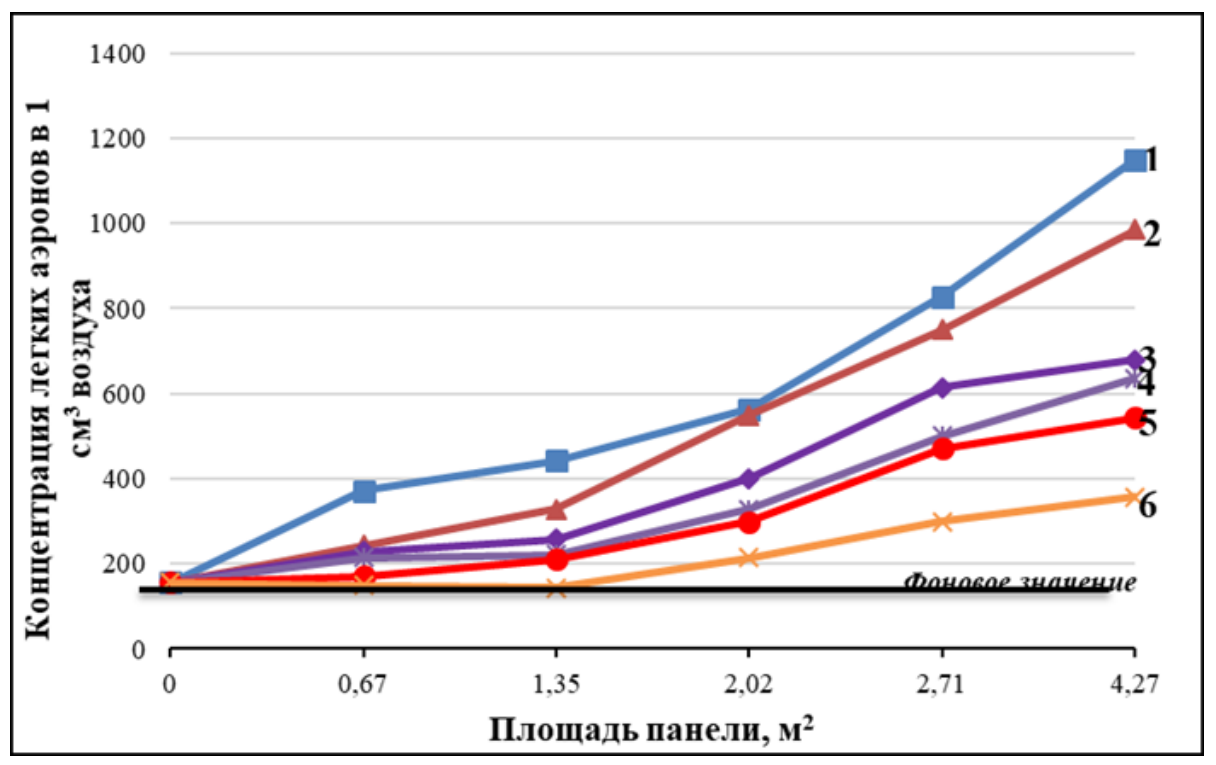

Рис. 3. Влияние площзади панели на концентрацию легких аэроионов.

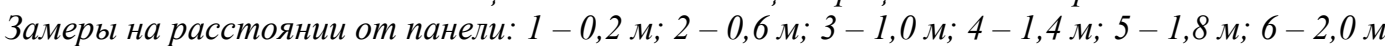


панели при ее площади более 1,35 м $^{2}$ явно приближались к прямым регрессиям.

Установлено, что концентрация легких аэроионов зависит от площади поверхности сильвинита и расстояния до нее, что необходимо учитывать при использовании сильвинита в хранилищах картофеля. Таким образом, при оценке условий хранения картофеля важно учитывать различные производственные и технологические факторы, влияющие на этот процесс [4-6].

Необходимо отметить, что прежде чем переходить к проектированию овощехранилищ, важно провести ряд лабораторных экспериментов, подтверждающих на практике возможность воздействия воздушной среды, контактирующей с калийными солями, на патогенные бактерии. Результаты таких экспериментов представлены ниже.

Для полноценного моделирования процесса были выделены изоляты фитопатогенных микроорганизмов путем прямого высева их на селективные среды из клубней картофеля с характерными признаками заболеваний - фитофтороза, фомоза, мокрой гнили и др. Образцы зараженных клубней картофеля отобрали в хозяйстве ООО «Труженик» Пермского края.

Известно, что к наиболее вредоносным и распространенным заболеваниям клубней картофеля в период хранения в средней полосе России относятся фитофтороз и сухая фузариозная гниль. С этой целью для выделения культур модельных фитопатогенов было отобрано по 3 образца клубней с признаками фитофтороза, фузариоза, мокрой бактериальной гнили и бурой гнили. Были получены культуры фитопатогенов, идентифицированных как представители родов Pectobacterium carotovorum, Phytophthora infestans, Fusarium. Выделенные изоляты выращивали на картофельно-сахарозном агаре, приготовленном следующим образом: на 1 л конечной среды 200 г картофеля варили 30 мин, фильтровали через марлю, к отвару добавляли 20 г сахарозы и 15 г агар-агара, растворяя их при нагревании, и автоклавировали 30 мин при 1 атм избыточного давления.

Проведено первичное моделирование свойств атмосферы и параметров хранения в условиях специальной климатической камеры. Изучено влияние соленасыщенной атмосферы на рост изолированных культур фитопатогенов с оценкой степени подавления роста. Для этого в герметичные камеры объемом 5,28 л помещали культуры фитопатогенов, посеянные на картофельный агар. В камере создавали соленасыщенную атмосферу за счет продувки воздухом через колоночный фильтр. Исследовали рост культур на чашках Петри с солью в трех вариантах: 1) объем потока воздуха через фильтр с солью 1 л/мин; 2) объем потока воздуха через фильтр с солью 0,1 л/мин; 3) в герметичной камере без вентиляции (с солью в открытых чашках Петри).

Эксперименты проводили при трех значениях относительной влажности: $16 \%$, $50 \%, 85 \%$ в соленасыщенной среде и в воздушной среде, пропущенной через стерилизующий мембранный фильтр. Степень подавления роста бактерий и грибов оценивали по числу колоний, формирующихся на чашках Петри с картофельным агаром из разведений $10^{-6}$ (табл. 1).

Развитие культур бактерий Pectobacterium carotovorum было максиТаблицуа 1

Количество колониеобразующих единиц в культурах патогенов картофеля Pectobacterium carotovorum и Phytophthora infestans при культивировании в соленасыщенной атмосфере

\begin{tabular}{|c|c|c|c||c|c|c|}
\hline & \multicolumn{3}{|c||}{ Pectobacterium carotovorum } & \multicolumn{3}{c|}{ Phytophthora infestans } \\
\hline $\begin{array}{c}\text { Влажность, } \\
\%\end{array}$ & $\begin{array}{c}\text { Атмосфрера } \\
\text { без соли, } \\
\text { КОЕ/чашка }\end{array}$ & $\begin{array}{c}\text { Соленасыщен- } \\
\text { ная атмосфрера, } \\
\text { КОЕ/чашка }\end{array}$ & $\begin{array}{c}\text { Подавле- } \\
\text { ние роста, } \\
\%\end{array}$ & $\begin{array}{c}\text { Aтмосфрера } \\
\text { без соли, } \\
\text { КОЕ/чашка }\end{array}$ & $\begin{array}{c}\text { Соленасыщенная } \\
\text { атмосфрера, } \\
\text { КОЕ/чашка }\end{array}$ & $\begin{array}{c}\text { Подавление } \\
\text { роста, \% }\end{array}$ \\
\hline 16 & $255,0 \pm 6,4$ & $194,7 \pm 4,8$ & 23,7 & $187,3 \pm 4,7$ & $113,3 \pm 4,6$ & 39,5 \\
\hline 50 & $326,0 \pm 10,6$ & $208,0 \pm 7,1$ & 36,2 & $308,7 \pm 7,3$ & $159,7 \pm 4,8$ & 48,3 \\
\hline 85 & $383,7 \pm 12,1$ & $212,7 \pm 5,4$ & 44,6 & $426,0 \pm 16,5$ & $212,7 \pm 5,4$ & 63,1 \\
\hline
\end{tabular}


мальным при влажности 85\%. При этом насыщение воздуха солью приводило к подавлению роста культуры фитопатогена на $23,7 \%$ при влажности $16 \%$, на $36,2 \%$ при влажности 50\% и на 44,6\% - при влажности 85\%. Абсолютное количество колоний было минимально в соленасыщенной среде с 16\%-ной влажностью.

Исследование влияния соленасыщенной атмосферы на Phytophthora infestans показало более выраженную зависимость от влажности среды и большую степень подавления роста в насыщенной аэроионами солей атмосфере. Подавление роста культуры данного фитопатогена происходило на 39,5\% при влажности 16\%, на $48,3 \%$ - при влажности 50\% и на 63,1\% при влажности $85 \%$.

Наличие конвекции оказывало влияние на выживаемость фитопатогенов (табл. 2). Установлено, что при создании потока соленасыщенного воздуха со скоростью 0,1 и 1 л/мин подавление роста фитопатогенов усиливалось.

Наиболее интенсивно подавлялся рост культуры при потоке 1 л/мин. При этом разность в количестве колониеобразующих единиц с вариантом без конвекции составляла 4,8\%. Показано также, что при повышении температуры воздуха (10, 20 и $\left.30^{\circ} \mathrm{C}\right)$, влияние соленасыщенной атмосферы пропорционально возрастает (табл. 3).

Такое возрастание подавляющего действия при повышении температуры может быть связано как с увеличением проницаемости клеточной оболочки для аэроионов, так и с большей чувствительностью клеток в условиях более интенсивных обменных процессов. Однако применение результатов проведенных исследований температурной зависимости на практике должно координироваться с физиологическими нормами температур хранения клубней картофеля в овощехранилище, предотвращающими их прорастание и потерю влаги. Как известно, оптимальными температурами для сохранности физиологической и товарной ценности здорового картофеля являются температуры $+15^{\circ} \mathrm{C}$ и менее, но не ниже $+1^{\circ} \mathrm{C}$. Во всех вариантах экспериментов соленасыщенная атмосфера оказывала как цитостатическое, так и цитотоксическое действие на фитопатогены (рис. 4).

Исследованиями влияния изменения влажности, конвекции, температуры контактирующей с солями воздушной среды на развитие и скорость передачи инфекций показано, что в соленасыщенной атмосфере эффективность экспери-

Таблица 2

Влияние конвекции на количество колониеобразующих единиц культур Pectobacterium carotovorum при культивировании в соленасыщенной атмосфере

\begin{tabular}{|c|c|c|c|c|c|c|c|}
\hline \multirow{2}{*}{ Влажность } & $\begin{array}{c}\text { Атмоссера } \\
\text { без соли, } \\
\text { КОЕ/ч }\end{array}$ & \multicolumn{2}{|c|}{$\begin{array}{c}\text { Соленасыщенная атмоссрера, КОЕ/чашка } \\
\text { конвекции }\end{array}$} & 0,1 л/мин & \multicolumn{3}{|c|}{ Подавление роста, \% } \\
\hline 0,16 & 255,0 & $194,7 \pm 4,8$ & $187,3 \pm 2,2$ & $182,3 \pm 2,9$ & $\begin{array}{c}\text { Без } \\
\text { конвекции }\end{array}$ & $\begin{array}{c}\text { Поток } \\
0,1 \text { л/мин }\end{array}$ & $\begin{array}{c}\text { Поток } \\
1 \text { л/мин }\end{array}$ \\
\hline 0,5 & 326,0 & $208,0 \pm 6,0$ & $197,7 \pm 3,5$ & $192,7 \pm 4,7$ & 36,2 & 39,5 & 28,9 \\
\hline 0,85 & 383,7 & $212,7 \pm 5,4$ & $198,7 \pm 3,7$ & $194,3 \pm 5,2$ & 44,6 & 48,2 & 40,9 \\
\hline
\end{tabular}

Таблица 3

Подавление роста культуры Pectobacterium carotovorum в соленасыщенной атмосфере при разных значениях температуры при скорости потока 0,1 л/мин, КОЕ/ч

\begin{tabular}{|c|c|c|c|c|c|c|c|}
\hline \multirow{2}{*}{ Влажность \% } & $\begin{array}{c}\text { Атмосфрера } \\
\text { без соли }\end{array}$ & \multicolumn{2}{|c|}{$\begin{array}{c}\text { Количество колониеобразующих } \\
\text { единиц (КОЕ/чашка) }\end{array}$} & \multicolumn{3}{c|}{$\begin{array}{c}\text { Подавление } \\
\text { роста, \% }\end{array}$} \\
\cline { 2 - 8 } & КОЕ/4 & $10^{\circ} \mathrm{C}$ & $20^{\circ} \mathrm{C}$ & $30^{\circ} \mathrm{C}$ & $10^{\circ} \mathrm{C}$ & $20^{\circ} \mathrm{C}$ & $30^{\circ} \mathrm{C}$ \\
\hline 16 & 255,0 & $192,3 \pm 5,9$ & $187,3 \pm 2,2$ & $116,3 \pm 4,4$ & 24,6 & 26,5 & 54,4 \\
\hline 50 & 326,0 & $204,0 \pm 4,6$ & $197,7 \pm 3,5$ & $120,7 \pm 6,2$ & 37,4 & 39,6 & 63,0 \\
\hline
\end{tabular}




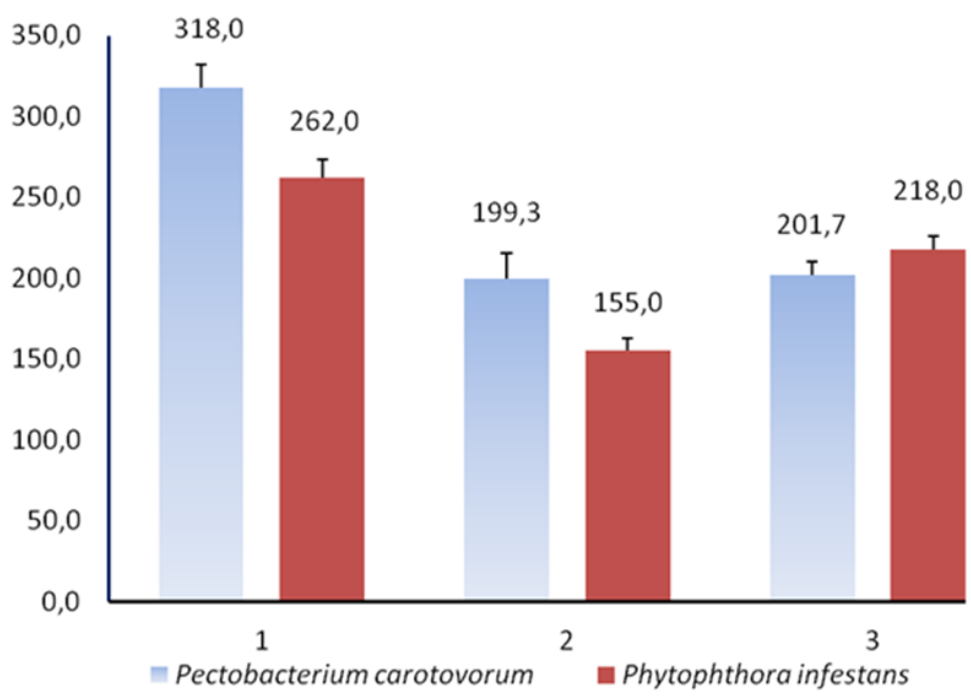

Рис. 4. Количество колониеобразующих единиц (КОЕ/чашка) при культивировании в соленасыщенной атмосфере и доращцвании в атмосфере без соли.

Варианты: 1 - контроль, без соли; 2 - соленасыщенная атмосфера; 3 -чашки, перемещенные в атмосферу без соли после 10-часовой инкубации в соленасыщенной атмосфере

ментального заражения, осуществляемого путем переноса суспензий фитопатогенных бактерий и грибов на срез картофеля, падала с $14-22$ до 2-7\% и с 16-29 до 6-11\%, соответственно.

В работе также рассматривалось соотношение цитостатического и цитотоксического действия воздушной среды, контактирующей с солями, в отношении возбудителей фомоза и фузариоза. Получены аналогичные результаты: соленасыщенная атмосфера снижала количество колониеобазующих единиц, однако в случае последующей инкубации в условиях без соли количество КОЕ возрастало (рис. 5).

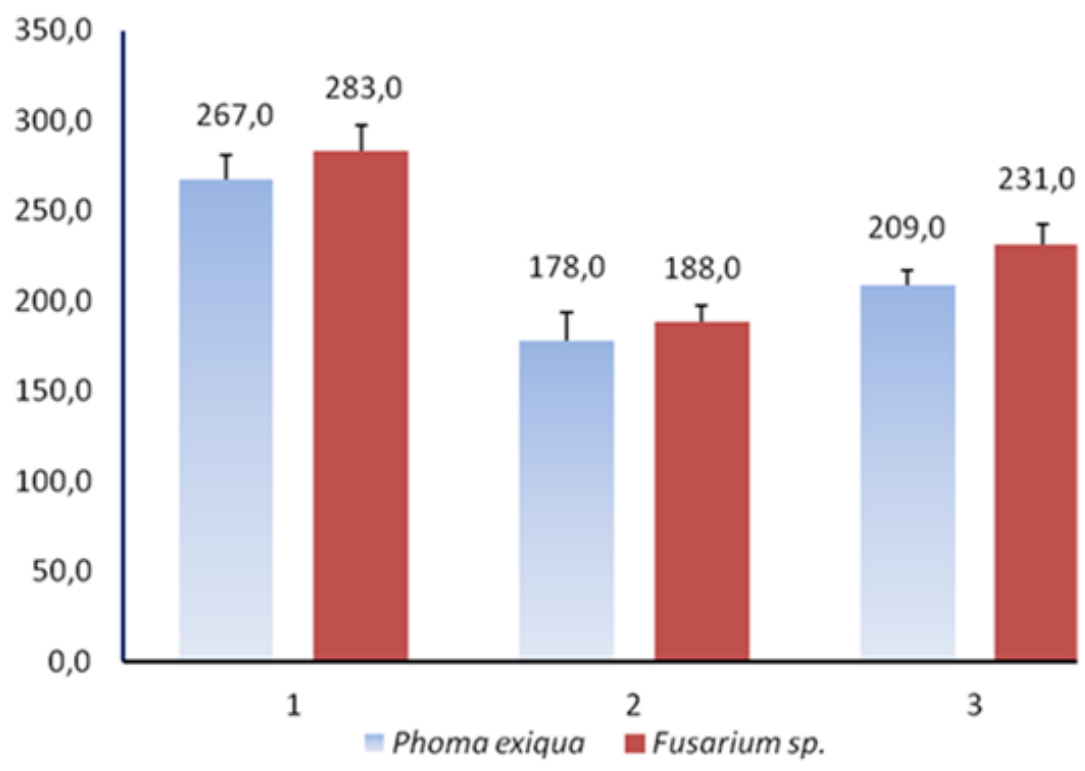

Рис. 5. Количество колониеобразующих единии (КОЕ/чашка) возбудителей фомоза и фузариоза при культивировании в соленасыщенной атмосфере и доращивании в атмосфере без соли.

Варианты: 1 -контроль, без соли; 2 - соленасыщенная атмосфера; 3 - чашки, перемещенные в атмосферу без соли после 10-часовой инкубации в соленасыщенной атмосфере 
Таким образом, полученные данные свидетельствуют о преимущественно фунгистатической природе защитного эффекта соленасыщенной атмосферы.

Наряду с исследованиями соотношения цитостатического и цитотоксического действия воздушной среды, контактирующей с солями, в отношении возбудителей фомоза и фузариоза, проведено исследование влияния размера частиц соли, получаемой в результате помола и сепарации, на эффективность подавления фитопатогенов. Фракции получали после механического дробления путем ручной сепарации с помощью стандартного исследовательского набора сит. Использовали фракции с размерами частиц 2,5-3 мМ, 1,5-2,5 мМ, 0,8-1,5 мм,

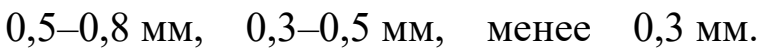
Эксперименты проведены по протоколу, описанному для вышеприведенных опытов с использованием разных фракций. Результаты представлены в табл. 4.

Как видно из полученных результатов, наилучший эффект показали наиболее мелкодисперсные фракции соли: 0,3-0,5 мм и менее 0,3 мм. Однако нужно учитывать, что использование самых мелкодисперсных фракций на практике технически затруднено вследствие кратно возрастающего сопротивления воздушному потоку через заполненные солью фильтры и применение фракции 0,5-0,8 мм на больших потоках будет более эффективным с точки зрения оптимизации затрат.

К семенному материалу картофеля, как и других сельскохозяйственных культур, предъявляются особенно высокие требования к загрязнению фитопатогенами. В то же время, в отличие от пищевого материала, семенной фонд может быть обработан веществами, присутствие которых в пищевых продуктах нежелательно или недопустимо (например, фунгицидами и другими биоцидами).

Как следует из ранее проведенных экспериментов, создание соленасыщенной атмосферы с определенными параметрами способствует лучшей сохранности картофеля при длительном хранении, однако не гарантирует отсутствие заражения, особенно грибкового. Последнее связано со способностью «грибов» - фитопатогенов картофеля переживать неблагоприятные для роста периоды за счёт спорообразования. Следует отметить, что для семенного фонда необходимы максимальные гарантии отсутствия патогенов.

В связи с этим были проведены эксперименты по изучению влияния обработки посадочного материала новым системным фунгицидом класса бутандионов - инканоном и создания соленасыщенной атмосферы на сохранность семенного картофеля.

В качестве фунгицидного средства использовали новый препарат инканон 4,4,4-трихлор-1-(4-хлорфенил) бутан-1,3-дион [1; с. 7].

Структурная формула инканона:<smiles>O=C(/C=C(\O)c1ccc(Cl)cc1)C(Cl)(Cl)Cl</smiles>

Эмпирическая формула: $\mathrm{C}_{10} \mathrm{H}_{6} \mathrm{Cl}_{4} \mathrm{O}_{2}$. Молекулярная масса: 299,96. Температура плавления: 74-76 ${ }^{\circ} \mathrm{C}$. Препарат представляет собой бесцветный кристаллический порошок, практически нерастворимый в воде, но хорошо растворимый в хлороформе, хлористом метилене, ацетоне, ДМСО, ДМФА, при нагревании в гексане, этаноле.

Определена его активность в отношении модельных культур и молекулярные механизмы противогрибкового действия: мембранотропная активность, повышение проницаемости клеточных оболочек [9].

Таблииа 4

Влияние размера частиц соли, получаемой в результате помола и сепарации, на эффективность подавления фитопатогенов (по снижению количества КОЕ)

\begin{tabular}{|c|c|c|c|c|c|c|}
\hline Фракция частиц соли & менее 0,3 & $0,3-0,5$ & $0,5-0,8$ & $0,8-1,5$ & $1,5-2,5$ & $2,5-3$ \\
\hline $\begin{array}{c}\text { Снижение количества } \\
\text { КОЕ, \% }\end{array}$ & $35,4 \pm 3,5$ & $33,1 \pm 2,4$ & $28,4 \pm 3,6$ & $24,9 \pm 2,6$ & $17,2 \pm 2,5$ & $13,1 \pm 4,2$ \\
\hline
\end{tabular}


Препарат инканона применяли в двух формах: чистого вещества (малорастворимо в воде) и растворимой калиевой соли. Обработку этим фунгицидом осуществляли методом аэрозольного распыления его раствором $0,02 \%$ при комнатной температуре перед началом экспозиции в соленасыщенной атмосфере. Опыты проводили с возбудителем фузариоза, как описано выше. Результаты экспериментов с совместным применением соленасыщенной атмосферы и фунгицида представлены в табл. 5.

Как видно из полученных результатов, сочетание обработки калиевой солью инканона и последующей инкубации в соленасыщенной атмосфере практически полностью гарантировало отсутствие жизнеспособных микромицетов в образцах.

Для исследования свойств воздушной среды в окружении пород калийных солей были разработаны лабораторные стенды, имитирующие конфигурацию современных картофелехранилищ, выполненных по типу бескаркасного арочного сооружения. Основой для стенда послужила теплица из металлического профиля 20×20 и поликарбоната, толщиной 4 мм. В стендах формировались разные условия за счет обеспечения различной площади поверхности сильвинита (рис. 6, 7). Дополнительно устанавливался контрольный стенд (без сильвинитовой поверхности).

Во время хранения картофеля параметры микроклимата поддерживали в соответствии с оптимальными значениями. Клубни семенного картофеля в течение всего периода хранения ежемесячно анализировали на выявление следующих фитопатогенов: фитофтороз, фузариоз, фомоз, кольцевая гниль, черная ножка, парша черная (ризоктониоз), парша (порошистая, обыкновенная, серебристая). За весь период хранения проанализировано по 17 клубней каждого варианта. При проведении анализов в течение всего периода хранения в контрольном варианте были обнаружены возбудители фомоза (3 клубня из 17), фитофтороза (3 клубня из 17), парши обыкновенной (5 клубней из 17), мокрой гнили (3 клубня из 17). В варианте с базовой дозой обнаружены возбудители фитофтороза

Таблица 5

\section{Влияние воздействия соленасыщенной атмосферы и нового системного фингицида из класса 1,3-бутандионов - инканона на сохранность семенного материала картофеля. Снижение количества КОЕ, \%}

\begin{tabular}{|c|c|c|c|c|c|}
\hline Вариант & $\begin{array}{c}\text { Соленасы- } \\
\text { щенная } \\
\text { атмосфрера }\end{array}$ & $\begin{array}{c}\text { Инканон, } \\
0,02 \%\end{array}$ & $\begin{array}{c}\text { Инканон- К } \\
\text { соль, 0,02\% }\end{array}$ & $\begin{array}{c}\text { Инканон 0,02\%+ } \\
\text { соленасыщенная } \\
\text { атмоссрера }\end{array}$ & $\begin{array}{c}\text { Инканон- К соль, 0,02\% } \\
\text { + соленасыщенная } \\
\text { атмосфрера }\end{array}$ \\
\hline $\begin{array}{c}\text { Снижение } \\
\text { количества } \\
\text { КОЕ, } \%\end{array}$ & $29,3 \pm 3,8$ & $91,6 \pm 4,9$ & $93,2 \pm 5,7$ & $98,5 \pm 1,5$ & 100 \\
\hline
\end{tabular}

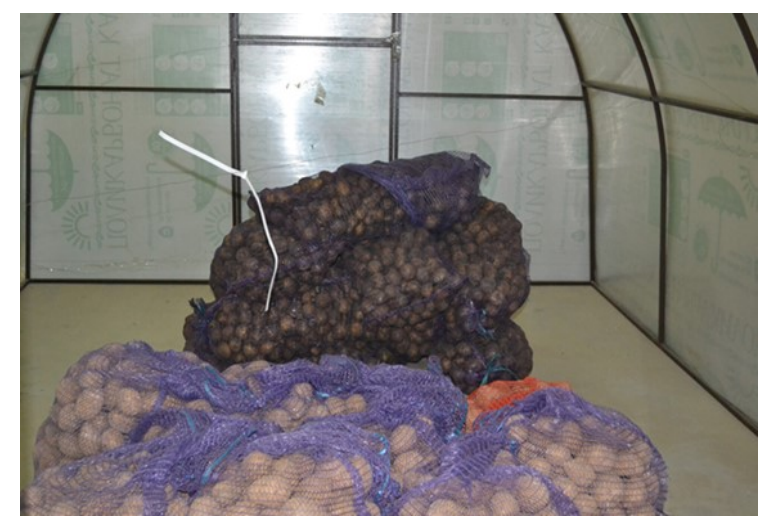

Рис. 6. Контрольный стенд с закладкой картофеля

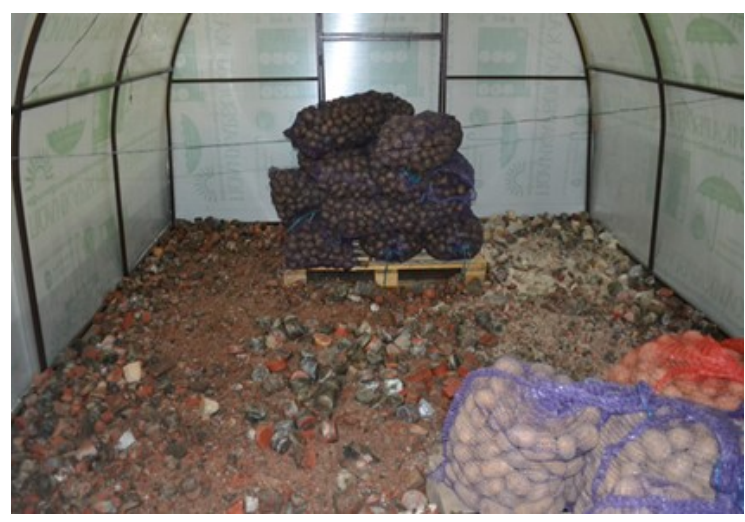

Рис. 7. Испьтательный стенд с сильвинитовой поверхностью 
(1 клубень из 17), парши обыкновенной (3 клубня из 17), мокрой гнили (1 клубень из 17). В варианте с двойной дозой калийной соли обнаружены возбудители фомоза (2 клубня из 17), фузариоза (1 клубень из 17), фитофтороза (2 клубня из 17), парши обыкновенной (2 клубня из 17).

Таким образом, за период хранения минимальное поражение клубней фитопатогенами наблюдалось в варианте с использованием насыпной поверхности базовой дозы калийной соли. В этом варианте из проанализированных 17 клубней патогены были обнаружены на 5. При использовании насыпной поверхности двойной дозы калийной соли из семнадцати проанализированных клубней было выявлено 7 зараженных. Максимальное количество инфицированных клубней определено в контрольном варианте (без использования калийной соли) - 14 из 17 (табл. 6).

Оценку лежкости картофеля проводили в апреле перед подготовкой к посадке. Клубни перебирали, удаляя больные с признаками сухой и мокрой гнили. Максимальное количество зараженных клубней с сухой гнилью отмечено у варианта с базовой дозой калийной соли, минимальное - в варианте с двойной дозой калийной соли, что составило $2,2 \%$ и $0,94 \%$, соответственно. Больные клубни с мокрой гнилью отбракованы в контрольном варианте - $0,43 \%$, в варианте с базовой дозой калийных солей $-0,37 \%$. Минимальное количество зараженных клубней с мокрой гнилью, отмеченное в варианте с двойной дозой калийной соли, составило $\quad 0,17 \%$. Максимальное количество больных клубней выявлено в варианте с базовой дозой калийной соли $(2,57 \%)$, минимальное - в варианте с двойной дозой калийной соли $-1,11 \%$ (табл. 7).

По результатам проведенного эксперимента можно сделать следующие выводы:

- применение калийной соли при хранении картофеля влияет на его биохимический состав. В конце периода хранения содержание сухого вещества в кон-

Таблица 6

Определение патогенов при хранении клубней картофеля

\begin{tabular}{|c|c|c|c|c|c|c|}
\hline Вариант & $\begin{array}{c}\text { Дата } \\
\text { отбора } \\
\text { образцов }\end{array}$ & $\begin{array}{c}\text { Фом03 } \\
\text { Phoma } \\
\text { exigu }\end{array}$ & Фузариоз & $\begin{array}{c}\text { Фитофттороз } \\
\text { Phytophthora } \\
\text { infestan }\end{array}$ & $\begin{array}{c}\text { Парша } \\
\text { обыкновенная } \\
\text { Streptomyces } \\
\text { scabies }\end{array}$ & $\begin{array}{c}\text { Мокрая гниль } \\
\text { Pseudomonas sp.+ }\end{array}$ \\
\hline \multirow{7}{*}{$\begin{array}{c}\text { Контрольный } \\
\text { вариант (без } \\
\text { использования } \\
\text { калийной соли) }\end{array}$} & 13.11.19 & $3 / 3$ & $0 / 3$ & $0 / 3$ & $0 / 3$ & $0 / 3$ \\
\hline & 10.12 .19 & $0 / 3$ & $0 / 3$ & $0 / 3$ & $0 / 3$ & $0 / 3$ \\
\hline & 13.01 .20 & $0 / 3$ & $0 / 3$ & $0 / 3$ & $1 / 3$ & $0 / 3$ \\
\hline & 14.02 .20 & $0 / 2$ & $0 / 2$ & $1 / 2$ & $0 / 2$ & $0 / 2$ \\
\hline & 13.03 .20 & $0 / 3$ & $0 / 3$ & $1 / 3$ & $2 / 3$ & $1 / 3$ \\
\hline & 14.04 .20 & $0 / 3$ & $0 / 3$ & $1 / 3$ & $2 / 3$ & $2 / 3$ \\
\hline & всего & $3 / 17$ & $0 / 17$ & $3 / 17$ & $5 / 17$ & $3 / 17$ \\
\hline \multirow{7}{*}{$\begin{array}{c}\text { С использованием } \\
\text { насыпной } \\
\text { поверхности } \\
\text { калийной } \\
\text { соли }-4,5 \text { м² } \\
\text { (базовая доза) }\end{array}$} & 13.11 .19 & $0 / 3$ & $0 / 3$ & $0 / 3$ & $1 / 3$ & $0 / 3$ \\
\hline & 10.12 .19 & $0 / 3$ & $0 / 3$ & $0 / 3$ & $0 / 3$ & $0 / 3$ \\
\hline & 13.01 .20 & $0 / 3$ & $0 / 3$ & $0 / 3$ & $0 / 3$ & $0 / 3$ \\
\hline & 14.02 .20 & $0 / 2$ & $0 / 2$ & $1 / 2$ & $1 / 2$ & $0 / 3$ \\
\hline & 13.03 .20 & $0 / 3$ & $0 / 3$ & $0 / 3$ & $0 / 3$ & $0 / 3$ \\
\hline & 14.04 .20 & $0 / 3$ & $0 / 3$ & $0 / 3$ & $2 / 3$ & $1 / 3$ \\
\hline & всего & $0 / 17$ & $0 / 17$ & $1 / 17$ & $3 / 17$ & $1 / 17$ \\
\hline \multirow{7}{*}{$\begin{array}{c}\text { С использованием } \\
\text { насыпной } \\
\text { поверхности } \\
\text { калийной } \\
\text { соли }-9,0 \text { м }^{2} \\
\text { (двойная доза } \\
\text { калийной соли) }\end{array}$} & 13.11 .19 & $2 / 3$ & $0 / 3$ & $0 / 3$ & $0 / 3$ & $2 / 3$ \\
\hline & 10.12 .19 & $0 / 3$ & $0 / 3$ & $2 / 3$ & $2 / 3$ & $0 / 3$ \\
\hline & 13.01 .20 & $0 / 3$ & $0 / 3$ & $0 / 3$ & $0 / 3$ & $0 / 3$ \\
\hline & 14.02 .20 & $0 / 2$ & $0 / 2$ & $0 / 2$ & $0 / 2$ & $0 / 2$ \\
\hline & 13.03 .20 & $0 / 3$ & $0 / 3$ & $0 / 3$ & $0 / 3$ & $0 / 3$ \\
\hline & 14.04 .20 & $0 / 3$ & $1 / 3$ & $0 / 3$ & $0 / 3$ & $0 / 3$ \\
\hline & всего & $2 / 17$ & $1 / 17$ & $2 / 17$ & $2 / 17$ & $0 / 17$ \\
\hline
\end{tabular}


Оценка лежкости клубней картофеля после периода хранения (снятие с хранения), сорт Горняк, апрель 2020 г.

\begin{tabular}{|c|c|c|c|c|c|c|c|}
\hline \multirow{3}{*}{ Вариант } & \multirow{3}{*}{$\begin{array}{c}\text { Общее количество, } \\
\text { кг }\end{array}$} & \multicolumn{6}{|c|}{ Количество зараженных клубней после периода хранения } \\
\hline & & \multicolumn{2}{|c|}{ сухая гниль } & \multicolumn{2}{|c|}{ мокрая гниль } & \multicolumn{2}{|c|}{$\begin{array}{l}\text { всего больных } \\
\text { клубней }\end{array}$} \\
\hline & & КГ & $\%$ & КГ & $\%$ & Кг & $\%$ \\
\hline Контроль & 175,5 & 2,30 & 1,30 & 0,75 & 0,43 & 3,05 & 1,73 \\
\hline $\begin{array}{l}\text { Базовая доза калийных } \\
\text { солей }\end{array}$ & 270,0 & 5,95 & 2,20 & 1,00 & 0,37 & 6,95 & 2,57 \\
\hline $\begin{array}{l}\text { Двойная доза калийных } \\
\text { солей }\end{array}$ & 270,0 & 2,55 & 0,94 & 0,45 & 0,17 & 3,00 & 1,11 \\
\hline
\end{tabular}

трольном варианте составляет 19,55\%, в варианте с базовой дозой $-18,55 \%$, в варианте с двойной дозой - $18,62 \%$. Содержание крахмала в варианте с использованием двойной дозой калийной соли составляет $13,04 \%$, у контрольного варианта - 13,49\%, максимальное содержание крахмала отмечено в варианте с базовой дозой калийной соли - 15,19\%. Содержание нитратов в контрольном варианте составило 36,8 мг/кг, в варианте использования базовой дозы калийной соли - 52,6 мг/кг, в варианте с двойной дозой калийных солей $-59,7$ мг/кг, что значительно ниже ПДК, которая составляет 250 мг/кг;

- за период хранения минимальное поражение клубней фитопатогенами наблюдается в варианте с применением насыпной поверхности базовой дозы калийной соли: из проанализированных 17 клубней патогены обнаружены на 5. При использовании насыпной поверхности с двойной дозой калийной соли из 17 проанализированных клубней выявлено 7 зараженных. Максимальное количество инфицированных клубней определено в контрольном варианте (без использования калийной соли) - 14 клубней из 17;

- оценка лежкости клубней картофеля выявила, что минимальное количество больных клубней обнаруживается в варианте с двойной дозой калийной соли $1,11 \%$, а максимальное - в варианте с базовой дозой калийной соли $-2,57 \%$;

- снижение потерь картофеля при хранении с солями возможно при покры- тии сильвинитом внутренней поверхности хранилища площадью не менее $30 \%$ и слоем не менее 50 мм.

В целом, проведенные исследования позволили установить, что природные калийно-магниевые соли обладают способностью продуцировать легкие аэроионы. Установлена зависимость концентрации таких аэроионов от площади сильвинитовой поверхности, что необходимо учитывать при использовании сильвинита в хранилищах картофеля. Так, при малых размерах панелей $\left(0,67-1,35\right.$ м $\left.^{2}\right)$ превышения концентрации легких аэроионов над средним фоновым значением ( $\mathrm{n} \pm \approx 165 \mathrm{~cm}^{-3}$ ) являются невысокими и составляют от 1,3 до 2,7 раза. При больших размерах панелей $\left(2,02 ; 2,70 ; 4,27 \mathrm{~m}^{2}\right)$ концентрация легких аэроионов превышает фоновую от 4,8 до 7,0 раз. Атмосфера с повышенным аэроионным фоном, а также присутствием мелкодисперсного соляного аэрозоля обладает защитным эффектом.

Установлено, что развитие культур бактерий Pectobacterium carotovorum было максимальным при влажности $85 \%$. При этом насыщение воздуха солью и аэроионами приводило к подавлению роста культуры фитопатогена на 23,7 \% при влажности $16 \%$, на 36,2\% - при влажности $50 \%$ и на $44,6 \%$ при - влажности $85 \%$. Абсолютное количество колоний было минимально в соленасыщенной среде с 16\%-ной влажностью. Исследование влияния соленасыщенной атмосферы на Phytophthora infestans показало ещё боль- 
шую зависимость от влажности среды и высокую степень подавления роста в насыщенной аэроионами солей атмосфере. Подавление роста культуры данного фитопатогена происходило на 39,5\% - при влажности 16\%, на 48,3\% - при влажности $50 \%$ и на 63,1\% - при влажности 85\%. Кроме того, изучено соотношение цитостатического и цитотоксического действия воздушной среды, контактирующей с солями, в отношении возбудителей фомоза и фузариоза. Соленасыщенная атмосфера снижала количество колониеобразующих единиц (КОЕ), в случае последующей инкубации в условиях без соли количество колониеобразующих единиц возрастало.

При проведении анализа хранения картофеля в моделях минихранилищ установлено, что использование калийной соли в насыпной поверхности повлияло на биохимический состав клубней картофеля. В конце периода хранения содержание сухого вещества в контрольном варианте составило 19,55\%, в варианте с базовой дозой - 18,55\%, в варианте с двойной дозой - 18,62\%. Содержание крахмала в варианте с использованием двойной дозы калийной соли составило 13,04\%, в контрольном варианте - 13,49\%, максимальное содержание крахмала отмечено в варианте с базовой дозой калийной соли $15,19 \%$. Содержание нитратов в контрольном варианте составило 36,8 мг/кг, в варианте использования базовой дозы калийной соли - 52,6 мг/кг, в варианте с двойной дозой калийных солей 59,7 мг/кг, что ниже ПДК, которая составляла - 250 мг/кг. Минимальное поражение клубней фитопатогенами было обнаружено в варианте с использованием насыпной поверхности базовой дозы калийной соли: из проанализированных 17 клубней патогены обнаружены на 5. Кроме того, снижение потерь картофеля при хранении с солями возможно при покрытии сильвинитом внутренней поверхности хранилища площадью не менее 30\% и слоем минерала не менее 50 мм.

Таким образом, разработана технология и показана возможность эффективного хранения картофеля с использованием калийных солей.

\section{Библиографический список}

1. Баландина С.Ю., Максимов А.Ю., Лисовенко Н.Ю., Шилова А.В. Новое противогрибковое соединение инканон из класса 1,3-бутандиона в опытах in vitro / Биофармацевтический журнал. 2019. - 11 (6). - C. 62-66.

2. Бачурин Б.А., Сметанников А.Ф., Хохрякова Е.С. Эколого-геохимическая оценка продуктов переработки глинисто-солевых шламов калийного производства // Современные проблемы науки и образования. - 2014. - № 6 [Электронный журнал] - URL: www.science-education.ru/120-15442 (дата обращения: 19.11.2014).

3. Груздева Е.В., Архипова В.В., Бучинская А.В., Кульчинская А.С. Технология применения комплексонов в жидких удобрениях и их роль в воде и почве [Электронный ресурс] URL: https:/www.waterh.net/wpcontent/uploads/2015/10/Article_09 (дата обращения 23.11.2019).

4. Гурбанова 3.Р., Гумбатов М.О., Гурбанов Э.А. Получение гранулированного фосфорного удобрения, обогащенного микроэлементами // Проблемы современной науки и образования. 2017. - № 6 (88). - C. 17-19.

5. Жевора С.В., Чугунов В.С., Шатилова О.Н., Анисимов Б.В. Современное состояние и прогноз производства картофеля в Российской Федерации // Материалы научно-практической конференции «Иновационные технологии селекции и семеноводства картофеля». - ФГБНУ ВНИИКХ. - 2017. - С. 3-27.

6. Зейрук В.Н., Мальцев С.В., Васильева С.В., Бызов В.А. Современные производственные факторы, определяющие биологическую и экономическую эффективность хранения картофеля // ХИПС. 2019. - № 3. - C. 20-28.

7. Мартыненко Л.И., Кузьмина Н.П. О влиянии комплексонов на биосферу // Химия комплексонов и их применение. - Калинин, 1986. - С. 3-28.

8. Сметанников А.Ф., Косолапова А.И., Бачурин Б.А. [и др.] Разработка методологического подхода в применении комплексных удобрений пролонгированного действия для зерновых культур, многолетних трав и картофеля // В сб.: Научные чтения памяти П.Н. Чирвинского, вып 21, - Пермь, 2018 - C. 415-423. 
9. Сметанников А.Ф., Оносов Д.В., Синегрибов В.А., Косолапова А.И., Новиков П.Ю. Патент РФ № 2497961 от 10.11.2013 г. «Способ переработки отходов калийного производства».

10. Старовойтова О.А., Старовойтов В.И., Манохина А.A. Влияние органического гранулированного удобрения и росторегуляторов на качество клубней картофеля // Аграрный вестник Верхневолжья. - 2018. - № 2 (23). - С.15-20.

11. Файнбург Г.З., Исаевич А.Г. Повышение сохранности картофеля при хранении в атмосфере, формируемой при помощи природных калийных солей. // Горное эхо. - 2019. - № 3. - С. 92-96.

\title{
INVESTIGATION INTO PHYSICAL AND CHEMICAL, ANTIBACTERIAL AND ANTIFUNGAL PROPERTIES OF THE AIR ENVIRONMENT FORMED UNDER THE INFLUENCE OF NATURAL POTASSIUM SALTS
}

\author{
A.V. Shalimov ${ }^{1}$, A.Y. Maksimov ${ }^{2}$, A.G. Isaevich ${ }^{1}$, L.G. Tsema ${ }^{3}$ \\ ${ }^{1}$ Mining Institute UB RAS \\ ${ }^{2}$ Institute of Ecology and Genetics of Microorganisms UB RAS \\ ${ }^{3}$ Perm Scientific Research Institute of Agriculture
}

\section{For citation:}

Shalimov A.V., Maksimov A.Y., Isaevich A G., Tsema L.G. Investigation into physical and chemical, antibacterial and antifungal properties of the air environment formed under the influence of natural potassium salts // Perm Federal Research Center Journal. - 2021. - № 2. - P. 34-46. https://doi.org/10.7242/2658-705X/2021.2.4

Russia has a huge potential for growing agricultural products. In this regard, the issue of preserving the grown crop and minimizing storage losses, which can reach $30-50 \%$, is very relevant. Currently, there are known methods for storing agricultural crops in storage facilities with active and natural ventilation in piles, bins, containers equipped with an airing system, systems for maintaining and controlling temperature and humidity. However, these methods do not provide high safety of product laid for long-term storage.

A promising direction for solving these problems is the use of the bactericidal properties of the air in contact with natural potassium salts. The Verkhnekamskoye Potassium Salt Deposit, one of the largest potash salt deposits located in Russia, contains a third of the world's reserves, which are mainly used for the production of potash fertilizers. However, the unique physical and chemical properties of natural potassium, sodium, and magnesium salts, as well as their mechanical and filtration characteristics, make it possible to significantly expand the scope of their use. In this regard, the paper describes the results of studies into the properties of the atmosphere in contact with natural potassium-magnesium salts and its effect on phytopathogens. The study of the effect of a salinesaturated atmosphere on Phytophthora infestans showed a greater dependence on the humidity of the environment and a greater degree of growth suppression in the atmosphere saturated with salt aeroions. The growth of this phytopathogen was suppressed by $39,5 \%$ at $16 \%$ humidity, by $48,3 \%$ at $50 \%$ humidity, and by $63.1 \%$ at $85 \%$ humidity. In addition, experiments on storing potatoes in an atmosphere in contact with natural potash salts showed minimal damage to tubers by phytopathogens when using the bulk surface of potassium salt.

Keywords: Natural potassium and magnesium salts, storage of potatoes, air ions, phytopathogens, the incidence of tubers, microorganisms.

\section{Сведения об авторах}

Шалимов Андрей Владимирович, доктор технических наук, ведущий научный сотрудник, Горный институт УрО РАН - филиал Пермского федерального исследовательского центра УрО РАН («ГИ УрО РАН»), 614007, г. Пермь, ул. Сибирская, 78a; e-mail: shalimovav@mail.ru

Максимов Александр Юрьевич, кандидат биологических наук, старший научный сотрудник лаборатории молекулярной микробиологии и биотехнологии, Институт экологии и генетики микроорганизмов УрО РАН - филиал Пермского федерального 
исследовательского центра УрО РАН («ИЭГМ УрО РАН»), 614981, г. Пермь, ул. Голева, 13; e-mail: almaks1@mail.ru

Исаевич Алексей Геннадьевич, кандидат технических наук, заведующий сектором рудничной вентиляции и горной теплофизики отдела аэрологии и теплофизики, «ГИ УрО РАН»; e-mail: aero_alex@mail.ru

Цёма Любовь Геннадьевна, кандидат сельскохозяйственных наук, старший научный сотрудник, Пермский научно-исследовательский институт сельского хозяйства - филиал Пермского федерального исследовательского центра УрО РАН («Пермский НИИСХ УрО РАН»), 614532, Пермский край, с. Лобаново, ул. Культуры, д. 12; e-mail: lyba_cema@mail.ru 